DOI: https://doi.org/10.32836/2521-666X/2018-2-60-11

УДК 658.29

\title{
Савіцький А.B.
}

кандидат економічних наук, доцент кафедри соціально-гуманітарної

та загальноекономічної підготовки,

Хмельницький кооперативний

торговельно-економічний інститут

\section{ПОБУДОВА СТРУКТУРИ СИСТЕМИ УПРАВЛІННЯ ПРИБУТКОВІСТЮ ПІДПРИЄМСТВА ЗА УМОВ ІНТЕГРАЦІЙНОЇ СПРЯМОВАНОСТІ ЕКОНОМІКИ}

У статті розглянуто основні аспекти управління прибутковістю підприємства в сучасних ринкових умовах. Наведено авторське обгрунтування поняття "система управління прибутковістю» як економічної категорії. Охарактеризовано особливості формування ланцюга прибутковості та напрямів взаємоузгодженості управлінських рімень щодо ї̈ підвищення. Виділено маркетинговий, ресурсний, інноваційний та функиіональний блоки як структуроутворюючі складники загальної системи управління прибутковістю підприємства в контексті основних елементів його інтегрованості до закордонних ринкових сегментів. Побудовано структуру системи управління прибутковістю підприємства на основі експортної стратегії розвитку.

Ключові слова: прибутковість, управління прибутковістю, прибуток, маркетинговий, ресурсний, інновачійний та функиіональний блоки управління прибутковістю, інтеграчія, експортна стратегія розвитку.

В статье рассмотрены основные аспекты управления прибыльностью предприятия в современных рыночных условиях. Приведено авторское обоснование понятия «система управления прибыльностью» как экономической категории. Охарактеризованы особенности формирования цепи прибыльности и направлений согласованности управленческих решений по ее повытению. Выделены маркетинговый, ресурсный, инновационный и функциональный блоки как структурообразующие составляющие общей системы управления прибыльностью предприятия в контексте основных элементов его интегрированности в зарубежные рыночные сегменты. Построена структура системы управления прибыльностью предприятия на основе экспортной стратегии развития.

Ключевые слова: прибыльность, управление прибыльностью, прибыль, маркетинговый, ресурсный инновационный и функциональный блоки управления прибыльностью, интеграция, экспортная стратегия развития.

\section{Savitskyi A.V. FORMATION OF ENTERPRISE'S PROFITABILITY MANAGEMENT SYSTEM STRUCTURE IN THE CONTEXT OF ECONOMY INTERGRATION ORIENTATION}

As of today, it is important for national enterprises of industrial production to take into consideration a lot of different views that concerns to the increasing approaches of its profitability level and financial results. The basic element of such research is dynamics of integration processes and its influence on the factual conditions of export production development that can make important potential for national producers in the direction of its profitability increase. That's why, it is actual for managers of industrial enterprises to research and form logic system of profitability management that allows to face the current market demands on the micro level, cooperation with WTO, integration to the EU and export strategy of Ukraine's development in the 2017-2021 period. In general, with the aim of enterprise's profitability increasing it is necessary to activate a lot of processes that concerns not only internal structure of production, but also impact of different changes in external environment. Such kind of interconnection and approving enterprise's activity in the sphere of profitability increasing depends on the level of its export orientation and integration to the foreign market structures. However, these processes can't be activated without a thoroughly thought-out management structure and the formation of a consistent interconnection of various production units. The basic elements of management decisions coherence are to become a logically through-out chain of profitability, the key tools for determining the effectiveness of its man- 
agement as monitoring and analysis of economic indicators, the results of which are aimed at the reduction of costs, increasing of profitability, quality improvement and production volumes growth. Taking into consideration all mentioned above, the management system of enterprise's profitability must consists not only of the specificity of formation and management decisions coherence on the level of its structural management units, but also of integration element in general management decisions, that are concerned to the enterprise's export activity increase. In addition, it is important to emphasize, that according to the place and role in manufacturing process, structural elements of export strategy and profitability management are contiguous.

Key words: profitability, profitability management, profit, marketing, resource, innovation and functional units of profitability management, integration, export strategy of development.

Постановка проблеми. Сьогодні для вітчизняних промислових підприємств важливо брати до уваги значну кількість різнобічних питань, які пов'язані $з$ підвищенням їхньої прибутковості та досягненням кращого рівня рентабельності. Ключовим елементом цієї проблематики є динамізм інтеграційних процесів країни та їх вплив на поточні умови розвитку експортоорієнтованого виробництва, яке створює значний потенціал для вітчизняного підприємства у напрямі підвищення його прибутковості. Тому для керівників промислових підприємств досить актуальним є дослідження та розроблення такої системи управління прибутковістю, яка здатна на мікрорівні відповідати сучасним вимогам ринку, співробітництва з СОТ, експортної стратегії розвитку України на 2017-2012 pр. та умовам інтеграції до $\mathrm{CC.}$

Аналіз останніх досліджень і публікацій. Проблемам вивчення питань управління прибутковістю підприємства за умов розвитку ринкових відносин присвячено праці таких учених, економістів та дослідників, як Л.М. Дзюбенко, В.В. Орлов, А. Рахішева, О.В. Федорова, 3.Я. Шацька. Водночас невирішеним питанням зазначеної проблематики залишається виділення особливостей побудови структури системи управління прибутковістю підприємства за умов інтеграційної спрямованості економіки.

Формулювання цілей статті. Метою статті є обгрунтування підходів та виділення особливостей формування складників і елементів структури управління прибутковістю підприємства за умов інтеграційної спрямованості економіки країни до закордонних ринкових структур.
Виклад основного матеріалу. Сучасні вимоги ринкової економіки, правила співробітництва з СОТ, лібералізація зовнішньої торгівлі та інтеграційні процеси дедалі ускладнюють умови розвитку вітчизняних підприємств промисловості. Насамперед це пов'язано 3 тим, що найбільш перспективними шляхами отримання прибутку суб'єктів господарювання та підвищення його прибутковості $є$ вихід на закордонні ринки та втримання потенційних конкурентних позицій на ньому. Виходячи з цього, на державному рівні необхідно створити низку можливостей, які дадуть змогу експортоорієнтувати вітчизняне виробництво на закордонні ринки ЄC. Важливим документом в цьому напрямі $\epsilon$ Експортна стратегія розвитку України («дорожня карта» стратегічного розвитку торгівлі) на 2017-2021 pp., яка висвітлює значну кількість важливих питань, що регламентують зовнішньоекономічну діяльність підприємств [2].

Виходячи 3 цього, будь-якому суб'єкта господарювання, який прагне зміцнити свої конкурентні позиції на зовнішньому ринку та досягти кращого рівня рентабельності, необхідно значну увагу приділяти формуванню продуманої системи управління підприємством. Прибутковість, як і будь-яка економічна категорія, здатна включати, акумулювати та поєднувати у собі низку взаємозалежних елементів, проте структура ії системи управління в кожного виробника буде відрізнятися в міру його потенційних можливостей. Водночас слід виділити те, що у цих питаннях також $є$ значна кількість спільних точок дотику, що здатні обгрунтувати управлінську діяльність підприємства через спільні структурні підсистеми і складники. 
На авторське бачення, під системою управління прибутковістю слід розуміти взаємоузгоджену послідовність управлінських рішень, що базується на аналізі економічних показників та оцінці можливостей ресурсів підприємства генерувати потрібну величину прибутку та рівень рентабельності. Ключовою є орієнтація організаційної та управлінської діяльності на зниження собівартості продукції, підвищення продуктивності праці, покращення якості та збільшення обсягів виробництва. Інструментами забезпечення окреслених процесів $є$ своєчасне та достовірне використання інформаційних ресурсів підприємства та ступінь інтегрованості управлінських рішень щодо підвищення прибутковості у загальній системі управління підприємством.

Лібералізація ринків та створення нових умов ведення зовнішньої торгівлі $є$ досить мінливими та для вітчизняних підприємств повною мірою здатні визначити подальші траєкторії їхнього розвитку, особливості виходу на іноземний ринок і характер дії тих чи інших структурних елементів управління у підвищенні прибутковості. 3 огляду на це, важливим у цій проблематиці має стати формування експортної стратегії діяльності підприємства у загальній системі управління його прибутковістю.

Насамперед для обгрунтування окреслених питань щодо формування структури системи управління прибутковістю підприємства необхідно звернути увагу на дослідження ланцюга управління прибутковістю Л.М. Дзюбенко. Згідно 3 дослідженнями вченої, базовими складниками ланцюга управління прибутковістю повинні бути водночас процеси вкладення витрат та примноження капіталу [1, с. 5]. На авторську думку, це слід пояснити тим, що в основі логічної постановки елементів ланцюга управління прибутковістю лежить капітал, який слугує джерелом витрат, що дають змогу отримати доходи, збільшити масу прибутку та активізувати функцію самозростання капіталу підприємства. 3 цих позицій слід вважати, що сутність зазначених процесів поклада- ється на системний підхід, який дає змогу зрозуміти те, що управління прибутковістю можливе лише за умови наявності у підприємства достатніх фінансових ресурсів. Чим більше коштів можливо вкласти у виробництво, тим більше суб'єкт господарювання матиме змогу підвищити прибутковість за рахунок збільшення маси прибутку. Як бачимо, елементи системності, управління та збільшення прибутковості на основі більшої кількості капіталу перебувають у нерозривному взаємозв'язку.

На додаток слід зазначити, що, на думку Л.М. Дзюбенко, у процес функціонування структури ланцюга управління прибутковістю підприємства мають бути покладені такі підсистеми організаційно-економічного забезпечення, як: результат, який має бути досягнуто за допомогою управління прибутковістю; учасники, які відповідають за досягнення результату, та їх взаємодія; ресурси та сукупність технологічних і технічних засобів для досягнення результату $[1$, с. 5].

3 огляду на вищевикладене слід зазначити, що сучасна система управління прибутковістю підприємства повинна бути досить функціональною та гнучкою, що можливо за умови взаємоузгодження та збалансованості iї елементів.

Для того щоб детальніше розглянути такі обгрунтування, необхідно навести думку О.В. Федорової, яка під основним критерієм економічної збалансованості та управління підприємством розглядає набір показників, що групуються за окремим економічним змістом, забезпечують досягнення потрібного рівня прибутковості та $\epsilon$ результатом управління діяльності підприємства. Автор вважає, що досягнення потрібного рівня прибутковості можливо забезпечити на основі збалансованості таких окремих економічних показників, як доходи, ціни, розмір і ставки податків та кредитів, амортизаційні відрахування, фінансові стимули тощо.

Виходячи 3 цього, необхідними інструментами загальної системи управління прибутковістю підприємства $є$ перспективний та 
ретроперспективний аналіз, які є частиною фінансово-економічного і фінансово-кредитного аналізу та на основі прогнозування, моніторингу, а також стратегічного планування забезпечують процес управління витратами та інвестиційно-інноваційною діяльністю. Результати зазначених видів аналізу визначають ефективність управління прибутковістю підприємства $з$ боку його економічної збалансованості [5, с. 7]. Тому досить вагомими структурними елементами у загальній системі управління прибутковістю підприємства слід вважати аналіз та моніторинг окремих показників, які за своїми значеннями будуть відповідати економічній доцільності залучення усіх видів ресурсів з метою досягнення очікуваного результату від здійснення процесів управління прибутковістю.

За умов бурхливого розвитку науково-технічного прогресу важливою рушійною силою, яка повинна бути закладена в основу активізації діяльності щодо підвищення прибутковості підприємства, $є$ інноваційна компонента його виробничих процесів. Насамперед це пов'язано з тим, що саме нові розробки та інноваційні продукти дають змогу посилити конкурентні позиції підприємства на ринку, сприяють отриманню більшого прибутку та формують потенційні можливості підвищення його прибутковості. Якщо взяти до уваги інтеграційну спрямованість економіки країни та умови формування ринкових відносин у ній, то невід'ємною частиною виробничого потенціалу кожного суб'єкта господарювання має стати його експортна орієнтованість на той чи інший сегмент ринку. Особливої актуальності це набуває тоді, коли за результатами виробничих процесів підприємство може мати позитивні фінансові результати.

Згідно 3 дослідженнями В.В. Орлова, ключовими блоками у структурі системи управління підприємством, яка орієнтована на інноваційну компоненту, а значить, і на підвищення прибутковості, $є$ маркетинговий, ресурсний та функціональний блоки управління [3, с. 156].
На авторське бачення, зазначений підхід можливо застосувати для обгрунтування структури системи управління прибутковістю підприємства, оскільки він включає усі аспекти активізації поетапного процесу виробництва продукції на експорт. Проте 3 метою окремого виділення експортоорієнтованості підприємства та ії значення у загальній системі управління його прибутковістю також необхідно виокремити й інноваційний блок управління.

Виходячи зі змісту авторського визначення, яке будо запропоновано нами вище, взаємоузгодженість управлінських рішень в межах маркетингового блоку системи управління прибутковістю пов'язана 3 аналізом показників якості та конкурентоспроможності продукції, ринкових досліджень, ціноутворення, асортиментної політики та позиціонування у свідомості споживачів. Управлінські рішення у структурі ресурсного блоку повинні узгоджуватися за допомогою аналізу показників кадрового, фінансового, технологічного та інфраструктурного забезпечення виробництва, а у структурі функціонального блоку - на основі аналізу можливостей реалізації стратегічних пріоритетів підприємства.

$\mathrm{He}$ менш важливими $є$ управлінські рішення, які спрямовані на розроблення інноваційних продуктів та реалізацію інноваційних проектів підприємства. Такі управлінські рішення узгоджуються на основі аналізу показників інноваційної компоненти виробництва та насамперед пов'язані 3 результативністю його експортної діяльності, що повною мірою залежить від сучасних вимог зовнішнього ринку та спроможності керівників структурних підрозділів впроваджувати нові інноваційні підходи до підвищення якості, стимулювання продуктивності праці, залучення інвестицій, розширення кола клієнтів, удосконалення логістичних сполучень, використання наявних ресурсів, зменшення собівартості, підвищення безпечності виробництва, знаходження вигідніших варіантів постачання сировини і матеріалів, диференціювання продукції та виконання умов контрактів. 
Водночас, на думку 3.Я. Шацької, будьякі управлінські рішення також повинні містити елемент інноваційності, який у разі їх взаємоузгодженості у системі управління прибутковістю має стосуватися окремого впливу суб'єктивних особливостей керівництва та об'єкт управління. До суб'єктивних особливостей керівництва слід віднести спроможність підприємства застосовувати стратегічний і проектний менеджмент, самоорганізовані та адаптивні підходи управління, реінжиніринг бізнес-процесів та співпрацювати 3 комерційними дослідницькими лабораторіями у напрямі розвитку експортного складника виробничої діяльності підприємства, а також його впливу на підвищення прибутковості. Об'єктами управління, в яких повинна міститись інноваційна компонента суб'єктивних управлінських рішень щодо підвищення прибутковості підприємства, є: персонал, виробництво, збут, постачання та логістика [6, с. 179]. Виходячи 3 того, що у процесі виробництва продукції на експорт здійснюється ретельний розрахунок iї собівартості, аналіз рентабельності та менеджмент якості, слід вважати, що саме на цьому етапі більшою мірою і визначається спроможність виробленої продукції принести підприємству ту чи іншу величину очікуваного прибутку.

Таким чином, інноваційний блок у структурі системи управління прибутковістю підприємства повною мірою повинен стосуватися специфіки призначення функціонального блоку управління. Наприклад, на думку А. Рахішевої, будь-яка організаційно-функціональна структура буде ефективною лише тоді, коли ключовими елементами iii побудови будуть мотиваційне, контрольне та регулятивне сприяння процесам виробництва $[4$, с. 214$]$.

На рис. 1 подана структура системи управління прибутковістю підприємства, яка сформована на основі вищенаведених досліджень та базується на теоретико-методологічному базисі взаємоузгодженості управлінських рішень, структурних елементів експортної стратегії та управління прибутковістю.
Згідно 3 рис. 1, слід зазначити, що загалом 3 метою підвищення прибутковості підприємства необхідно активізувати низку необхідних процесів не тільки всередині внутрішньої структури підприємства, але й 3 урахуванням різних динамічних змін зовнішнього середовища. Такий характер взаємозв'язку та покращення діяльності підприємства у напрямі підвищення його прибутковості повною мірою залежить від того, наскільки підприємство $є$ експортоорієнтованим та інтегрованим у закордонні структури ринку. Проте зазначені процеси неможливо активізувати без ретельно продуманої структури управління та формування послідовного взаємозв'язку різних ланок виробництва. Основою прийняття та взаємоузгодженості необхідних управлінських рішень має стати логічно продуманий ланцюг прибутковості, ключовими інструментами визначення ефективності їі управління - моніторинг та аналіз економічних показників, результатом - зниження собівартості, підвищення продуктивності праці, покращення якості, збільшення обсягів виробництва.

Висновки. Отже, в основі системи управління прибутковістю підприємства лежить не тільки важливість специфіки формування та взаємоузгодженості управлінських рішень на рівні іï структуроутворюючих блоків управління (маркетинговому, ресурсному, інноваційному та функціональному), а й їх інтегрованість з управлінськими рішеннями, які мають бути розроблені щодо активізації експортної діяльності підприємства. Не винятком $\epsilon$ i те, що за результатами проведених нами досліджень структурні елементи експортної стратегії та управління прибутковістю відповідно до їх місця у побудові виробничого процесу є суміжними. Таким чином, $з$ метою підвищення рівня прибутковості насамперед підприємству необхідно провести конструктивні та виважені маркетингові дослідження стосовно виходу виробленої продукції на іноземний ринок, акумулювати необхідні ресурси, залучити капітал, впровадити інновації та застосувати нові методи роботи. 


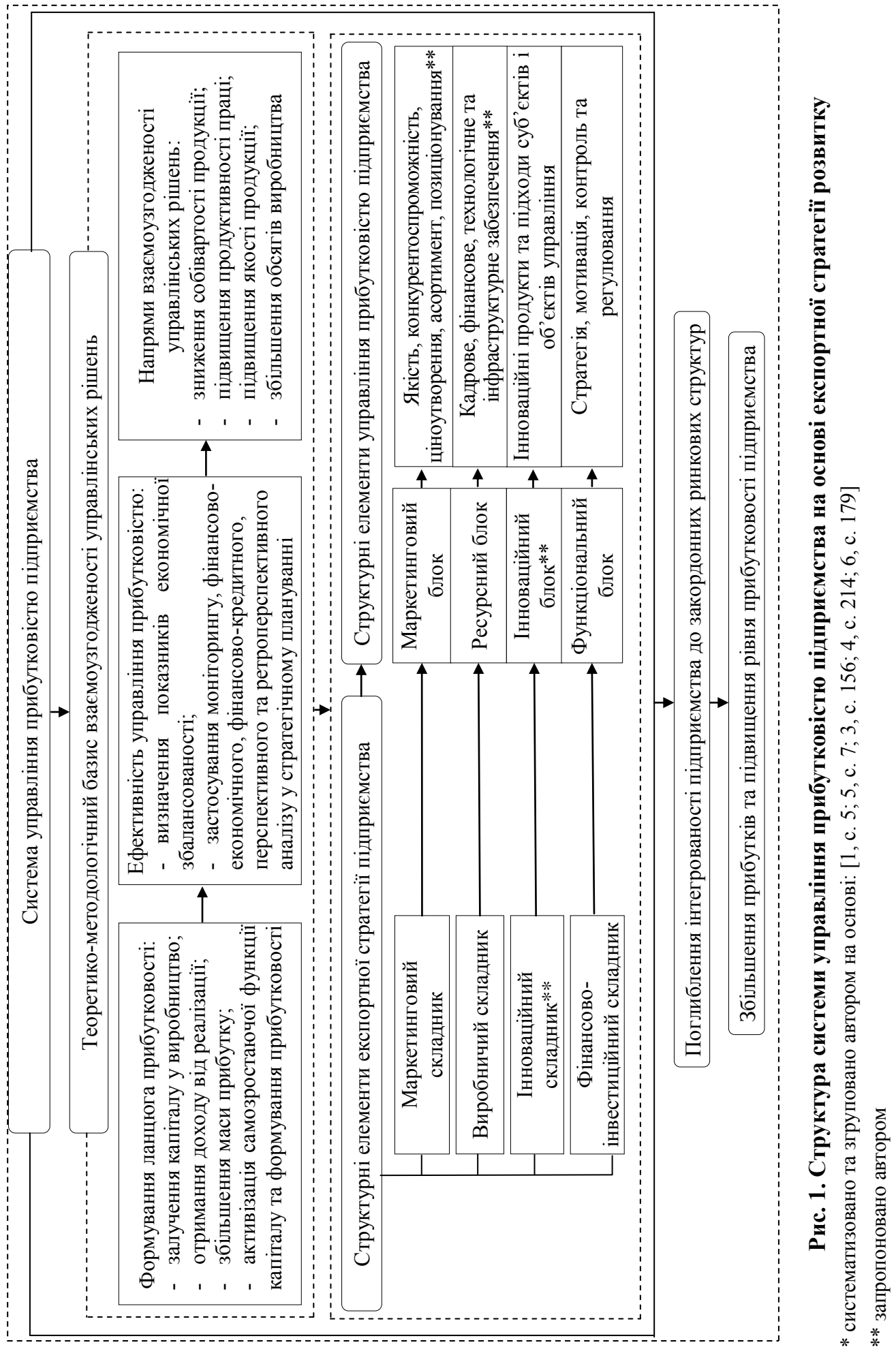




\section{Список використаних джерел:}

1. Дзюбенко Л. М. Організаційно-економічне забезпечення прибутковості підприємств : автореф. дис. ... канд. екон. наук : 08.00.04. Київ, 2007. 21 с.

2. Експортна стратегія розвитку України («дорожня карта» стратегічного розвитку торгівлі) на 2017-2021 pp. : розпорядження Кабінету Міністрів України від 27 грудня 2017 р. № 107-p. URL: https://https://www.kmu.gov.ua/ua/npas/pro-shvalennya-eksportnoyi-strategiyiukrayini-dorozhnoyi- karti-strategichnogo-rozvitku-torgivli-na-20172021-roki.

3. Орлов В.В. Концептуальні основи управління інноваціями у маркеинговій товарній політиці підприємств. Актуальні проблеми економіки. № 10 (148). С. 153-159.

4. Рахішева А. Організація ефективного менеджменту на промислових підприємствах. Актуальні проблеми економіки. 2014. № 3 (153). С. 211-219.

5. Федорова О.В. Збалансованість як метод управління прибутковістю підприємств : автореф. дис. ... канд. екон. наук : 08.00.04. Київ, 2007. 23 с.

6. Шацька 3.Я. Управлінські інновації в системі підприємства. Актуальні проблеми економіки. 2012. № 1 (127). С. 1176-182. 